\title{
ASSESSMENT PRIOR TO SEX RECONSTRUCTIVE SURGERY.
}

\author{
Asim Kr. Mallick ${ }^{1}$, Rajarshi Guha Thakurta ${ }^{2}, \mathrm{S.N} \mathrm{Ali}^{3}$
}

\section{INTRODUCTION :}

The transsexual phenomenon has been mentioned from time to time in recorded history. Indian mythology has in it, many references to altered sexual states. ${ }^{1}$ The name Ardhanarishwara refers to God, who is half man and half woman, an androgynous deity. In various versions of Ramayana, there is reference to King Ila,who spent half his life as man and half as woman. In Mahabharata, Arjuna,one of the fiercest warriors of his time, spent ayear of his life in intersexed condition. There is also reference to King Bangasvana, who was changed into a woman by Lord Indra, whom he had offended. Another reference during Mahabharata is to Shikhandini. He was born female, but raisedlike a man and trained in warfare. After an encounterwith a Yaksha, Shikhandini came back as a man, was called Shikhandi and fathered children.

Harry Benjamin (1885-1986) recognized transsexualism, treated hundreds of patients and established the modern scientific management of this condition ${ }^{2}$.

In 1979, Harry Benjamin's International Gender Dysphoria Association (HBIGDA) was founded. They established the transsexual Standards of Care (SOC's) and established the criteria for diagnosis, management and surgery ${ }^{3}$. The World Professional
Association for Transgender Health (WPATH), formerly known as the (Harry Benjamin International Gender Dysphoria Association, HBIGDA), is a professional organization devoted to the understanding and treatment of gender identity disorders.

While 'sex'represents physical differentiation as male or female, indicated by theexternal appearance of genitalia and the presence of gonads, 'gender' is the psychological recognition of self, and wish to be regarded by others, as fitting into the social categories such as boy/man or girl/woman. In short, sex is what one is seen as (external appearance as male/ female) and gender being the identity is what one feels (playing the role of and living the life of male/ female).

\section{TREATMENT OPTIONS :}

Feminizing/masculinising hormone therapy will induce physical changes that are more congruent with a patient's gender identity ${ }^{5}$. Treatment options include voice and communication therapy to help clients adapt theirvoice and communication in a way that is both safe and authentic, resulting in communication patterns that clients feel are congruent with their gender identity and that reflect their sense of self.

1. Dept. of Psychiatry, Burdwan Medical College \& Hospital.

2. Calcutta National Medical College \& Hospital.

3. Central Institute of Psychiatry, Ranchi 


\section{Gastern Cournal of Exychiatry}

\section{SURGERY:}

One of the pre-requisites for gender reassignment surgery includes a firm diagnosis for the transsexual condition $^{6}$. Thecriteria for these are:

1. A sense ofdiscomfort and inappropriateness about one's sex.

2. A wish to be rid of one's genitalia and the desire to live life as a member of the opposite sex.

3. This discomfort/disturbance has been continuously present for a minimum of 2 years and is not limited to aperiod of stress.

4. An absence of physical intersex or genetic abnormality.

All assessments should include a thorough physical exam, including weight, height, and blood pressure. This also includes breast, genital,and rectal exams, which are sensitive issues for most transsexual, transgender, and gender-nonconforming patients, and should be based on individual risks and preventive health care needs.

Hormonal Therapy for Adolescents: Hormonal treatment should be conducted intwo phases only after puberty is well established.

1. In the initial phase, biological males should be administered an antiandrogen (which neutralizes testosterone effects only) or an LHRH agonist (which stops the production of testosterone only). Biological females should be administered sufficient androgens, progestins, or LHRH agonists (which stops the production of estradiol, estrone, and progesterone) to stop menstruation.

2. Second phase treatments--After these changes have occurred and the adolescent's mental health remains stable, biologic males may be given estrogenic agents and biologic females may be given higher masculinizing doses ofandrogens. Second phase medications produce irreversible changes.

Prior to Age 18

In selected cases, the real life experience can begin at age 16, with or without first phase hormones. The administration of hormones toadolescents younger than age 18 should rarely be done.Monitoring for adverse events should include both clinical and laboratory evaluation. Specialists may include speech-language pathologists, speech therapists. Surgeryparticularly genital surgeryis often the last and the most considered step in the treatment process for gender dysphoria.In ordinary surgical practice, pathological tissues are removed to restore disturbed functions, or alterations are made to body features to improve a patient's self image ${ }^{8}$. Typical elective procedures involve only a private mutually consenting contract between a patient and a surgeon.

Genital and breast/chest surgeries as medically necessary treatments for gender dysphoria are to be undertaken only after assessment of the patient by qualified mental health professionals. The number and sequence of surgical procedures may varyfrom patient to patient, according to their clinical needs. Genital surgical procedures for FtM female to male) patients may include hysterectomy,salpingooophorectomy,vaginectomy,metoidioplasty,scrotoplasty, urethoplasty, placement of testicular prostheses, and phalloplasty. Surgical complications of $\mathrm{MtF}$ (male to female) genital surgery may include complete or partial necrosis of the vagina and labia, fistulas from the bladder or bowel into the vagina, stenosis of the urethra, and vaginas that are either too short or too small for coitus. Another aspect is the consent for the procedure and safeguarding the 
surgeon or the gender team from future litigation. Though waiver of liability, spousal release and parental consent forms are available, there is an absence of legal backing.At completion of GAS, a Gender Certificate shouldbeissued to the patient by the gender team consistingof the operating surgeon, psychiatristand endocrinologist.

\section{References :}

KalkinathArdhanarishwara - the god who is half woman [Internet] U.K. Available from:

http://philhine.org.uk/writings/tt_ardhanarishvara.html [cited 2008 Sep 25]

2. Ardhanari [Internet] From Wikipedia, the free encyclopedia. Available from: http://en.wikipedia.org/wiki/Ardhanarishvara [cited 2008 Sep 25]

3. Elephanta Caves [Internet] From Wikipedia, the free encyclopedia. Available from:

http://en.wikipedia.org/wiki/Elephanta_Caves [cited 2008 Sep 26]

4. Shikhandi [Internet] From Wikipedia, the free encyclopedia. Available from:

http://en.wikipedia.org/wiki/Shikhandi [cited 2008 Sep 25]

5. Timeline Transgender History [Internet] Transgender Health U.K. Social Resources. Available from: http://www.transgenderzone.com/features/timeline.htm [cited 2009 Apr 28]
Though GAS has been legally allowed in U.K. since 1967, in U.S.A. since 1972, and invarious other countries, Indian Laws are silent on the issue $^{8}$.Renewed efforts are necessary from the Indian lawmakers in this regard.

6. Hatshepsut [Internet] From Wikipedia, the free encyclopedia. Available from:

http://en.wikipedia.org/wiki/Hatshepsut [cited 2008 Sep 25]

7. Hawass Z. Quest for the Mummy of Hatshepsut [Internet] Available from:

http:/www.guardians.net/hawass/articles/quest_for_the_mum my_of_hatshepsut.htm [cited 2009 May 21]

8. Christina of Sweden [Internet] From Wikipedia, the free encyclopedia. Available from:

http://en.wikipedia.org/wiki/Christina_of_Sweden [cited 2008 Sep 25] 